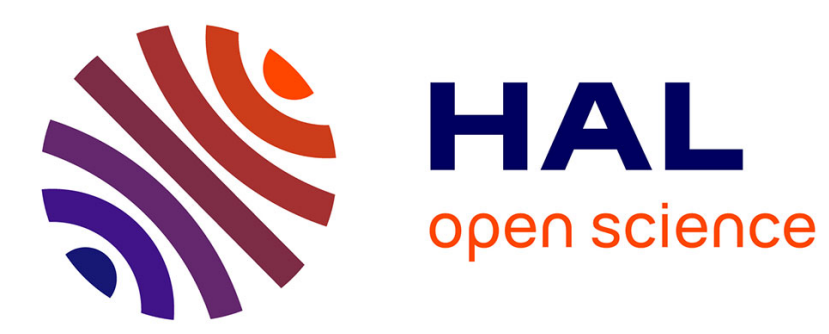

\title{
Sled acceleration control for low speed impact testing and transient response studies
}

Baptiste Sandoz, Antoine Simonin, Dominique Saletti, Sébastien Laporte

\section{To cite this version:}

Baptiste Sandoz, Antoine Simonin, Dominique Saletti, Sébastien Laporte. Sled acceleration control for low speed impact testing and transient response studies. Computer Methods in Biomechanics and Biomedical Engineering, 2014, 17 (SUPP1), pp.48-49. 10.1080/10255842.2014.931105 . hal01065602

\section{HAL Id: hal-01065602 https://hal.science/hal-01065602}

Submitted on 18 Sep 2014

HAL is a multi-disciplinary open access archive for the deposit and dissemination of scientific research documents, whether they are published or not. The documents may come from teaching and research institutions in France or abroad, or from public or private research centers.
L'archive ouverte pluridisciplinaire HAL, est destinée au dépôt et à la diffusion de documents scientifiques de niveau recherche, publiés ou non, émanant des établissements d'enseignement et de recherche français ou étrangers, des laboratoires publics ou privés. 


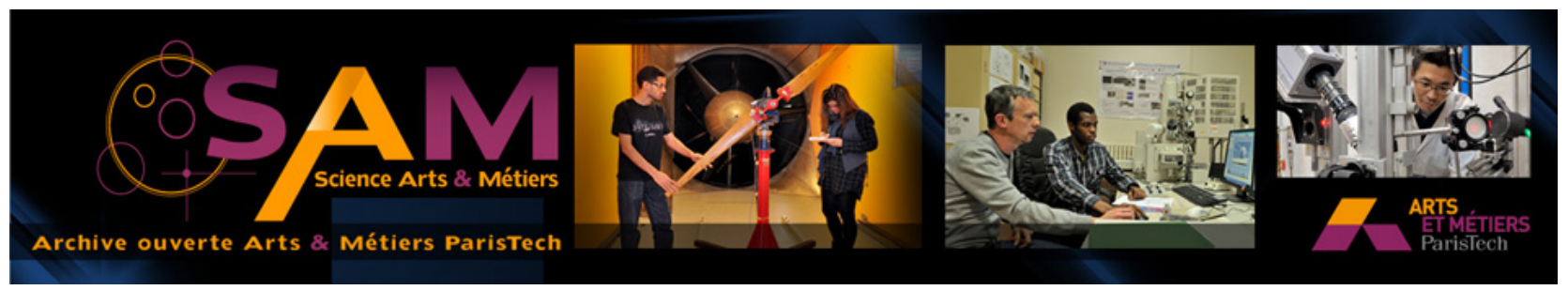

\section{Science Arts \& Métiers (SAM)}

is an open access repository that collects the work of Arts et Métiers ParisTech researchers and makes it freely available over the web where possible.

This is an author-deposited version published in: http://sam.ensam.eu

Handle ID: .http://hdl.handle.net/10985/8558

\section{To cite this version :}

Baptiste SANDOZ, Antoine SIMONIN, Dominique SALETTI, Sébastien LAPORTE - Sled acceleration control for low speed impact testing and transient response studies - Computer Methods in Biomechanics and Biomedical Engineering - Vol. 17, nSUPP1, p.48-49 - 2014 


\title{
Sled acceleration control for low speed impact testing and transient response studies
}

\author{
B. Sandoz ${ }^{\text {a* }}$, A. Simonin ${ }^{\mathrm{a}}$, D. Saletti ${ }^{\mathrm{a}}$ and S. Laporte ${ }^{\mathrm{a}}$ \\ ${ }^{a}$ Arts et Metiers ParisTech, LBM/IBH-GC, 151 bd de l'Hopital, 75013 Paris, France
}

Keywords: sled; impact biomechanics; jerk; acceleration; automation

\section{Introduction}

Whiplash Associated Disorder is the most common soft-tissue injury arising from low-speed car crashes (Siskind et al. 2013). To better understand whiplash injury mechanisms in the head-neck system, a sled was acquired. The sled was previously controlled in open loop mode, without any feedback of the resulting motion. The aim of this project is to safely control the motion and acceleration of the sled in order to be able to generate reproducible acceleration profiles.

\section{Methods}

A 5-meter sled was attached to the floor and controlled by a three-phase servo-motor (Compumotor APEX640), through a driver (Compumotor APEX40). In order to increase the torque, a toothed belt reduction connects the motor to the main toothed belt, which is able to set a $850 \mathrm{~mm}$-diameter wooden pad plate in motion (Figure 1).

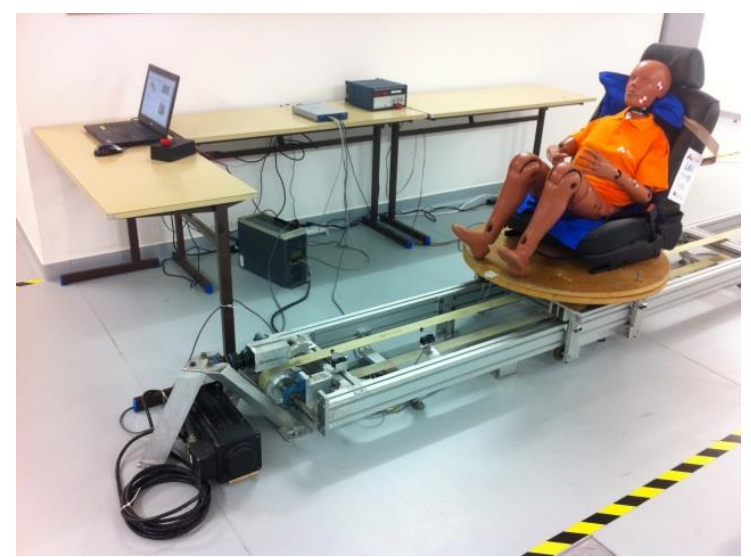

Figure 1 Global view of the sled.

Depending on the experimental conditions during a test, friction and mass may influence the response of the system. An open loop control system cannot evaluate this error. Consequently, a closed loop control has been developed.

The numerical regulation, input signal generation, filtering, error calculation and correction of the input signal were performed with LabView $^{\odot}$. Control of the closed loop was achieved with a
Proportional-Integral-Derivative controller (PIDcontroller), a widely used system which is easy to implement. Each parameter of the PID-controller was experimentally identified in order to have a compromise between accuracy, stability and swiftness.

Feedback control was performed with two sensors: a tachometer gave the rotational speed of the motor itself, and a one-axis accelerometer was directly mounted into the wooden pad fixation with the main belt $( \pm 50 \mathrm{~g}$, SM-B50 Sensel Measurement). First, the servo-control of the speed was tested using a Heaviside step function. However, the aim is to control the sled's acceleration, therefore the servo-control of acceleration was tested using both a Heaviside step function and a sinusoidal function (Equation 1). This sinusoidal function has the effect of minimizing jerk.

$$
a(t)=\frac{A}{2}\left(1-\cos \left(\frac{2 \pi t}{T}\right)\right)
$$

Equation 1

\section{Results and Discussion}

The first experiment regarding the servo-control of the speed using the tachometer led to no static error (the motor reached the prescribed conditions), and the response was close to that of a second order system.

The Heaviside step function applied to the acceleration led to no static error. However, it was essential to filter the accelerometer signal because the accelerometer was very sensitive to sled vibration. A non-negligible phase difference was then observed.

Finally, the sinusoidal acceleration input signal led to an error close to zero (Figure 2). The amplitude of the signal and the phase difference are linked to the gain level of the filter. A low gain value does not entirely remove the vibration but reduces the phase difference between the filtered and nonfiltered signal. 


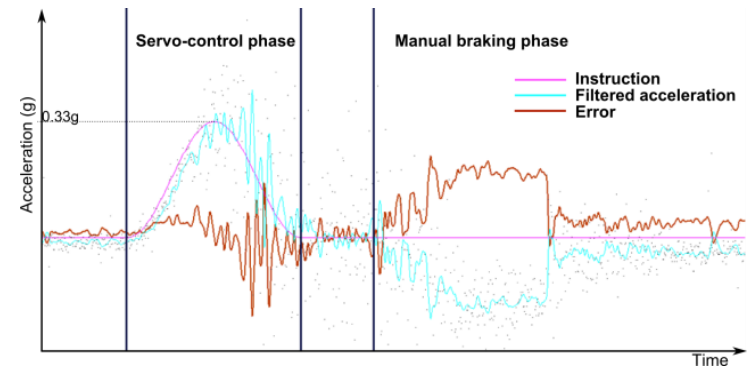

Figure 2 Response to the sinusoidal acceleration input signal.

Due to a limited length of the sled, all experiments were performed during very short time intervals. Moreover, the deceleration during the braking phase must also be safely controlled in order to be less than the starting acceleration.

It was observed that vibrations increased with velocity. One source of vibration is the toothed belts, another belt profile with better grip could possibly reduce this noise. However, even if vibrations have relatively high amplitudes compared to the input signal, they have a very small influence on motion, such that the rotational speed of the motor shows no jerk. This is due to the PID regulation which filters variations to the corrected input signal.

\section{Conclusions}

To conclude, we successfully controlled sled motion in closed loop mode for both speed and acceleration. Even though vibrations are substantial under some conditions, it was not necessary to filter the sensor signal with a high gain value, avoiding introducing a significant phase difference.

Future work is planned to define several PIDcontroller parameters, according to the mass placed on the moving pad. Eventually, the aim is to have a robust tool to apply repeatable and safe accelerations for biomechanical tests.

\section{Acknowledgments}

This research was partly funded by a grant from the FSR (Fondation Sécurité Routière) in the frame of the Whiplash project.

\section{References}

Siskind V, Sheehan M, Rakotonirainy A, Cockshaw W. 2014. Road crash risk after Whiplash Associated Disorder. Safety Science. 63:151156. 